\title{
POETRY
}

\section{Being on call for dead men}

Previously published at www.cmaj.ca

Dead men call. I tell them the most important thing,

wisdom dangling like a jumper from my stethoscope. "If love were true,

then we'd all have spotlights on." Dead men are past all things,

despaired of earth, and I listen to the sepulchre, to an age.

Dead men have one word: Why, and my bedside manner fades

to the dizzily anemic physican to the rich and famous,

to the medicine man who says Shazam and turns into a shaman,

who cannot heal himself and says, Friend, I reassure.

Dead men know where that goes. I take their calls at odd hours.

There is no home visit for Why, no two aspirins, no complete physical. If I could take the pulse of Mr. Melanson, his threadiness beating a bush telegraph,

or peer deeply into the white blood cells of Mr. House, their maws lip synching We Shall Succumb, l'd learn the mien needed for not-long men

who call me by my first name, who order affairs according to the settling of pain. The true is a roll call. I write Now as the cause of death on the certificate.

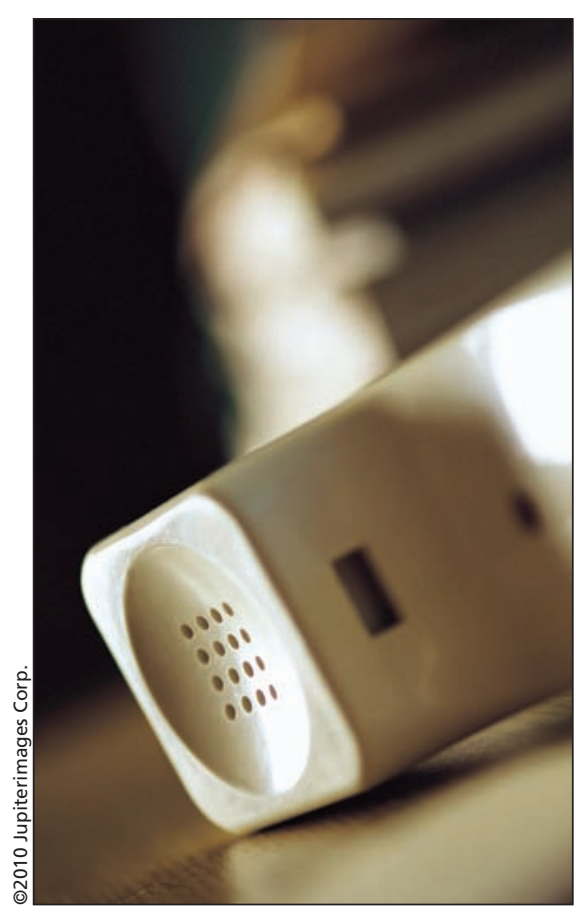

\section{Shane Neilson MD}

Family physician

Guelph, Ont. 